\title{
Implementasi Strategi Komunikasi Kesehatan dalam Meyakinkan Masyarakat untuk Pelaksanaan Vaksinasi COVID-19 di Kabupaten Barito Kuala
}

\author{
Rika Apriany Sukmana, Muhamad Iwu Iyansyah, Bambang Adi Wijaya, Marhaeni Fajar \\ Kurniawati \\ Program pasca sarjana ilmu komunikasi Universitas Islam Kalimantan \\ Muhammad Arsyad Al Banjari \\ Email authors: sukma.batola@gmail.com, iwuiyansyah89@gmail.com, \\ bmbng.669@gmail.com, marhaeni.akbar@gmail.com
}

\begin{abstract}
ABSTRAK
Peningkatan virus covi19 terus meningkat dalam kurun waktu terakhir ini, dan kita lakukan sinergitas semua elemen bangsa dalam menekan laju penambahan kasus positif Covid-19. vaksinasi segera dilakukan kepada seluruh warga masyarakat, Pemerintah Pusat melalui Kementerian Kesehatan telah menyusun langkah-langkah terkait pelaksanaan vaksinasi tersebut. Beberapa media konvensional yang bisa dipergunakan dalam rangka komunikasi vaksinasi Covid-19 yakni melalui TV nasional, radio dan media cetak. Vaksinasi akan meningkatkan imunitas/daya tahan tubuh pada orang dan masyarakat. Yang akhirnya akan memberikan perlindungan kepada individu dan masyarakat. Tapi dengan tetap disiplin menerapkan pencegahan Covid-19 melalui 3M yaitu terus menggunakan masker, mencuci tangan dan menjaga jarak. Diplomasi pemenuhan kebutuhan vaksin Covid-19 terus dilakukan untuk meyakinkan dan mengamankan vaksin tersebut dengan kerjasama antar negara dan badan Internasional, Bilateral maupun Multilateral. Kemudian, Kementerian Kesehatan juga telah menyiapkan peraturan yang tidak hanya sekedar tertib namun akuntabel terhadap Sumber Daya Manusia (SDM), administrasi, logistik, jaringan fasyankes dan sistem monev untuk pelaksanaan vaksinasi Covid-19. Perlindungan terhadap tenaga kesehatan menjadi hal yang perlu diperhatikan. Meskipun vaksinasi saat ini sudah dilaksanakan, seluruh masyarakat maupun tenaga kesehatan tetap harus menerapkan protokol kesehatan. Diimbau kepada masyarakat, khususnya warga Barito Kuala untuk melakukan vaksin Covid-19, demi kesehatan kita bersama, bahwasannya vaksin itu aman, vaksinasi diberikan untuk mayoritas masyarakat.
\end{abstract}

Kata Kunci: Media Komunikasi, Implementasi Strategi Komunikasi Kesehatan.

\section{PENDAHULUAN}

Penanganan Covid-19 di Indonesia memasuki situasi baru, seiring dengan kabar proses vaksin covid 19 sudah mulai menemukan titik terang. Bahwa proses uji klinis (fase 3) masih berlangsung, sehingga belum dapat dipastikan khasiatnya, pemerintah-beranggapan bahwa pengadaan vaksin covid 19 perlu dilakukan segera sebagai langkah preventif penyediaan vaksin. Upaya preventif ini juga sebagai respon dimana semua negara berlomba-lomba memperebutkan vaksin ini agar ekonomi bisa segera bangkit dan warga menjadi pulih kembali (Ihsanuddin, 2020).

Dalam bahasa sederhana ten-tang pembelian barang sebelum barang ada atau sedang berproses ini dikenal dengan istilah ijon. Indo-nesia meng-ijon vaksin covid 19 dari China melalui tiga perusahaan, yakni Cansino, G42/Sinopharm dan SinoVac. Konon vaksin dari ke-tiga perusahaan ini sudah melakukan tes tahap tiga di berbagai negara. 
Presiden Joko Widodo da-lam pidatonya di sidang umum PBB pada 23 September 2020 menyatakan bahwa vaksin ini bakal menjadi pengubah permainan (game changer) dalam upaya memerangi pandemi covid 19 (CNN Indonesia, 2020). Sikap optimisme kepala negara atas jalan yang akan ditemp-uh dalam memberantas penyebaran covid 19 yang tentu saja perlu dilihatbagaimana perwujudan kebi-jakan yang akan diambil nantinya.

Soal vaksin covid 19 memang menjadi wacana kekinian yang ku-rang lebih ditunggu banyak orang, setelah dilanda pandemi covid 19. Virus ini berhasil memaksa setiap orang menahan diri dari aktivitas sosial. Virus ini juga berhasil memaksa pemerintah menggunakan kekuasaan negara yang dalam pe-ngertian Max Weber, bahkan, bisa menggunakan kekerasan fisik secara sah (Gerth \& Mills, 1958; Budiardjo, 2008). Pemerintah juga mengatur ketertiban terhadap masyarakat berdasarkan sistem hukum yang diselenggarakan dan karenanya diberikan kekekuasaan memaksa (MacIver, 1926 dalam Budiardjo, 2008).

Meski ada kerangka penga-manan diri dan orang lain yang terus dikampanyekan, seperti meng-gunakan masker, menjaga jarak, mencuci tangan, dan sebagainya, tetapi itu bukan dianggap solusi untuk menjalankan aktivitas sosial secara bebas. Dalam persoalan inilah Indonesia bahkan diprediksi akan menjadi sentrum pandemi covid 19 setelah Wuhan (Sari, 2020) sebagai penilaian atas kelambanan pemerintah didalam menangani penyebaran.

Pada pertengahan November 2020, tercatat lebih 470 ribu orang yang terkonfirmasi positif covid 19. Angka ini terus meningkat dan menyentuh angka 1 juta lebih di penghujung Januari 2021. Dari sejumlah orang yang terkonfirmasi positif, yang meninggal lebih dari 29 ribu orang, dan sembuh lebih dari 852 ribu orang (covid19.go.id, 2021).

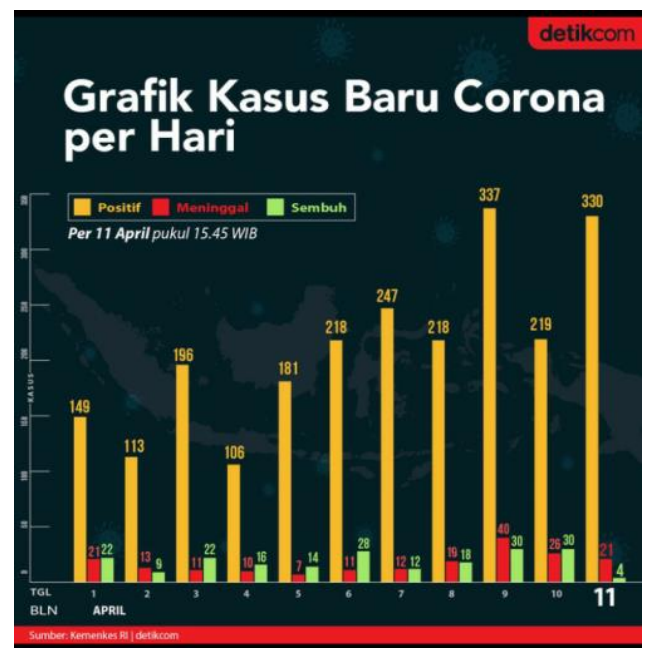

Gambar 1. Perkembangan Kasus Terkonfirmasi Positif Covid-19 Sumber: covid19.go.id

Sejauh ini, kemungkinan orang yang terkonfirmasi akan cenderung terus naik. Karena itu, kewajiban pemerintah untuk selalu menjaga kesehatan warga negara dan men-cari cara agar dapat menyelesaikan virus ini hingga tuntas. 


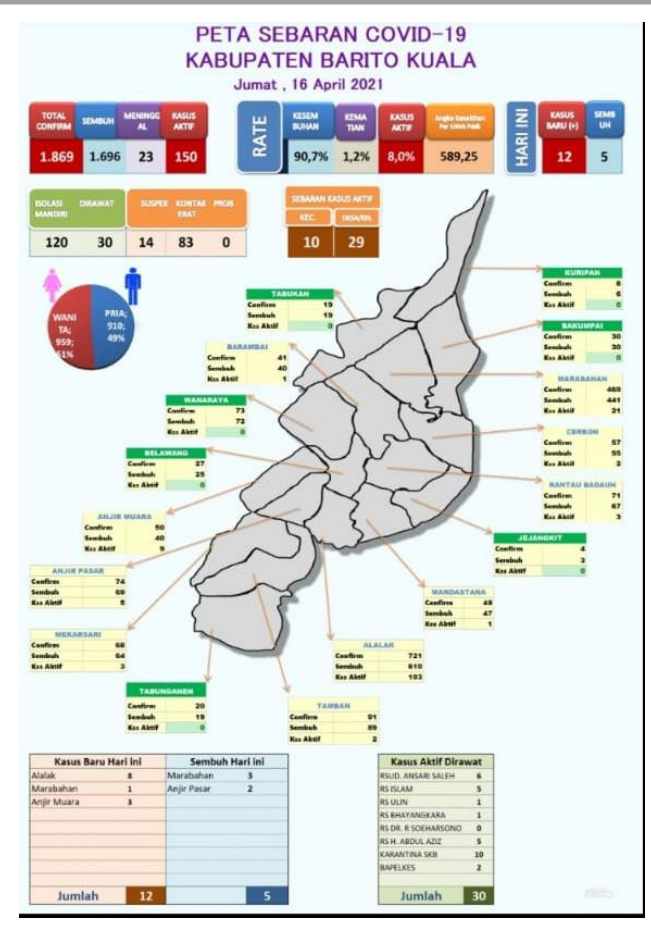

Gambar 2.Kasus Covid 19 di Barito Kuala

Sumber: Satgas Covid Batola

Dengan fakta di atas, membeli vaksin dan melakukan vaksinasi covid 19 memang menja-di jalan paling rasional untuk memutus mata rantai penyebaran. Namun, bagaimana respon masyarakat atas usaha pemerintah yang membeli vaksin meski masih dalam tahap uji klinis? Akhir Oktober 2020,Kemenkes RI merilis hasil survey, bersama Indonesian Technical Advisory Group on Immunization (ITAGI) tentang respon masyarakat atas rencana melaksanakan vaksinasi covid 19 . Hasilnya, 64,8\% masya-rakat bersedia divaksinasi, 7,6\% menolak dan 26,\% masih ragu (CNNIndonesia, 2020).

Setiap orang sepakat bah-wa vaksinasi adalah sesuatu yang krusial dilakukan. Pemerintah juga sedang gencar melakukan sosialisasi pentingnya vaksinasi ini untuk memutus rantai penyebaran covid 19. Namun, mengapa respon masyarakat tidak menyentuh angka maksimal? Katakanlah 99\% (plus minus MoE jika menggunakan sam-pling $1 \%$ asumsi penulis) mau divaksinasi untuk menggambarkan bahwa tidak ada penolakan dan keraguan orang Indonesia terha-dap niat pemerintah memberikan vaksin covid 19 ini? Apakah orang-orang masih relatif belum meyakini sepenuhnya vaksin ter-sebut nanti berefek terhadap peningkatan imunitas tubuh dari serangan covid 19?

Ataukah, semua ini terkait kepercayaan (trust) masyarakat terhadap pemerintah Indonesia yang lemah. Sebagaimana disam-paikan Chris Miller Dalam COVID-19 Crisis: Political and Economic Aftershocks bahwa sejak wabah Covid-19 merebak telah terjadi krisis kepercayaan (Problem of Trust) warga negara terhadap kekuasaan. Miller mencontohkan sejumlah kepala negara seperti Moon Jae In (Korea Selatan), Shinzo Abe (Jepang), dan Donald Trump (AS) mendapat-banyak kritik atas keti-dak mampuan mereka menanga-ni virus dan membiarkan korban terjangkit terus bertambah (Miller, 2020).

Penelitian ini menggunakan penelitian kualitatif yang oleh Nicholas Walliman dinilai sebagai sebuah analisis penelitian terhadap kata-kata yang berkaitan dengan ide,gagasan, kepercayaan, perasaan, kebiasaan dan perilaku manusia (Walliman, 2011). Analisis yang digunakan oleh penulis bersifat deskriptif analitis untuk memberi-kan gambaran bagaimana per-spektif ekonomi politik meman-dang fungsi negara dan pemerintah didalam program vaksinasi covid 19. 
Pengumpulan data di-lakukan melalui studi literatur (sekunder) dengan menelaah sumber-sumber dari berbagai literatur seperti jurnal, buku, dokumen, website,media, dan lain sebagainya. Sementara, teknik analisis data dalam penulisan artikel ini berangkat dari penjelasan Creswell (2014) yang memfokuskan analisa data melalui pengorganisasian data, pembacaan dan pencatatan,serta pendeskripsian, peng-klarifikasian, serta penafsiran (Agustino, 2020).

\section{METODE PENELITIAN}

Metode penelitian kualitatif studi kasus merupakan metode yang relevan digunakan dalam penelitian ini. Dengan menggunakan pendeka-tan ini penulis juga dapat mem-berikan pandangan yang kompre-hensif dan mendalam mengenai media informasi kesehatan.

Definisi lain mengenai studi kasus diungkapkan oleh Robert K. Yin. Yin menyatakan bahwa studi kasus merupakan suatu inkuiri empiris yang menyelidiki fenomena di dalam konteks kehidupan nyata, bilamana batas-batas antara fenome-na dan konteks tidak tampak dengan tegas dan dimana multi sumber bukti Definisi studi kasus lebih tepat mengarah pada pencarian kasus dengan menggunakan pertanyaan how dan why untuk memperoleh hasil penelitian yang akurat dan lengkap (Yin, 2003: 18).

Adapun data primer dalam penelitian ini telah diperoleh dari pihak-pihak terkait langsung melalui teknik pengumpulan data, sebagai berikut:

1. Observasi atau pengamatan yang dilakukan terhadap perilaku infor-man

2. Wawancara langsung secara mendalam dari informan peneli-tian

Studi Literatur yang dilakukan dengan menggunakan berbagai referensi yang relevan misalnya jurnal atau penelitian terdahulu

\section{HASIL DAN PEMBAHASAN}

Pemerintah Indonesia juga mendapat banyak kritik atas penanganan covid 19, dan itu belangsung hingga ke tahap pembelian covid 19 ini. Mengapa? Sebab, kebijakan yang diambil ini terkesan tergesa-gesa tanpa disertai pembuktian empiris akan kekhasia-tan lanjutan vaksin. Terkesan pula bahwa ada niatan mencari keuntungan ekonomis dengan memaksakan penggu-naan produk ini menggunakan tangan kekuasaan dan kepentingan negara. perspektif ekonomi politik memandang feno-mena ini. Sehingga, tidak sekedar mesimplifikasi persoalan kedalam dikotomi perdebatan yakin atau ragu; mau atau tidak.

Diakui atau tidak, terpaan pan-demi covid 19 ini sangat kuat menampar kemapanan banyak negara. Covid 19 dalam laporan organisasi inter-nasional akan men-jadi pemicu resesi global (Inman, 2020). Ibarat fenomena yang terjadi di awal abad ke-20 saat dunia diguncang wabah Spanish Influenza dan menyebabkan jutaan orang menemui kematian. Penyakit ini juga menimbulkan great depression dan mampu meng-hentikan perang dunia I (Keagen, 2020; Whiting, 2020).

Perubahan besar juga terjadi di era yang lebih kontemporer seperti mewabah-nya virus yang menyebabkan sakit Swine Flu. Flu jenis ini bermula di Amerika Serikat, dan ditetapkan sebagai pandemi oleh WHO pada tahun 2009. Seperti halnya covid 19, flu jenis ini juga telah menyebabkan jatuhnya korban sakit dan meninggal dunia. Akibat ekonomi yang ditimbul-kan cukup besar dan mengakibatkan kontraksi eko-nomi global yangserius (Aubin, 2009). Flu ini ikut membidani lahirnya sistem nasional pelayanan vaksin, khususnya di Amerika Serikat (Calmes \& McNeil, 2009; Purwanto \& Emilia, 2020 ). 
Vaksin 19 jika dipandang dalam kacamata ekonomi politik bukan hanya sekedar obat atau alat peningkat imunitas tubuh dari penularan covid 19 semata. Vaksin covid 19 juga berasosiasi dengan kepentingan ekonomi politik banyak negara. Di dalamnya terkandung dominasi kekuasaan bahkan hegemoni dan infiltrasi kepen-tingan pasar suatu negara.

Dengan kata lain, vaksin 19 berkorelasi terhadap kepentingan negara dalam kerangka mencipta-kan sumber-sumber kekayaan baru dan mening-katkan pendapatan. Keberadaan vaksin 19 juga me-minjam istilah Caporaso dan Lavine (2015)-merupakan bentuk dari "kekuasaan yang terkondisikan". Sebab dalam hal ini negara mem-bangun relasi kekuasaan dengan entitas swasta (perusahaan, kapita-lis dan organisasi pekerja dan konsumen) untuk sama-sama memproduksi dan mendistribusikan kekayaan.

Kekuasaan yang terkondisi pada dasarnya merupakan situasi dalam tatanan sosial yang bekerja sedemikian rupa sehingga memuas-kan kebutuhan dari beberapa kalangan tertentu dan menyesatkan kesaadran dari kalangan lain, dan mengira bahwa kepentingan dari kalangan yang diuntungkan adalah sama dengan kepentingan mereka sendiri (Caporaso \& Levine, 2015).

Dalam kondisi yang mem-butuhkan, ditambah kelangkaan produk dan permintaan yang sudah pasti tinggi, maka mekanisme pasar memang berlaku. Persoalan di dalam negeri adalah bagaimana agar ketersediaan terhadap vaksin juga terjaga, maka langkah untuk membeli diawal dan menjalin kontrak pembelian dengan perusa-haan asing menjadi pilihan pemerintah.

Fungsi pemerintah memang seperti itu, yakni memiliki tanggung jawab domestic untuk menjamin kebutuhan masyarakat (Rasyid, 2000). Namun, pemerintah tak seharusnya hanya memikirkan soal ketersedian. Ada hal krusiallain yang tak kalah genting, yakni memas-tikan bahwa pemerintah tidak menjadikan rakyat sebagai pangsa pasar untuk meraih keuntungan yang sebesar-besarnya dan bertindak selayaknya perusahaan yang ber-upaya memperoleh kekuasaan pasar (market power) (Caporaso \& Levine, 2015).

Pemerintah diharapkan tidak mengeluarkan kebijakan yang kontra produktif dengan tujuan bernegara dan mengkonstruksikan tujuan penyelesaian covid 19 dengan memaksakan logika pasar kepada rakyat (chibibi, 2019). Jika mengu-nakan logika pasar maka pasar memiliki kekuasaan "Mengendali-kan" Negara untuk menyediakan semua komoditas yang mendukung keberlang-sungan pasar (kapitalisme) .Dukungan tersebut berupa pembangunan infa-struktrur, kebijak-an kompetisi dan segala urusan yang terkait dengan kepentingan pasar.

Oleh karena itu, Negara harus memiliki prinsip-prinsip didalam penentuan regulasi terkait mekanis-me pasar, yaitu: (1) mengenai efisiensi, pasar harus dibangun secara sosial melalui serangkaian peraturan yang disepakati atau diberlakukan dalam permainan. (2) tidak ada mekanisme pemasaran alami atau spontan sehingga perlu diatur sebaik mungkin oleh pemerin-tah.(3)prinsipnya sederhana kalau pasar itu menggunakan prinsip equilibrium maka ia adalah hasil dari kepatuhan terhadap sebuah peratur-an (Boyer \& Drache, 1996). Dengan kata lain, Negara harus mengambil peran besar untuk memastikan kebijakan lebih terarah dan tuntas.

Pemerintah harus melihat kondisi saat ini dimana rakyat masih dalam kondisi terpuruk akibat dari dampak covid 19 ini. Kenormalan baru hanya merubah budaya keseharian perilaku dan aktivitas, tanpa bisa merubah keadaan ekonomi masyarakat pada kenormal-an yang layak. Lantas, apakah negara tidak boleh sepenuhnya mendapat-kan keuntungan? Mungkin pernyataan ini bisa dijawab dengan pernyataan pula, apakah Negara tetangga menghitung keuntungan di tengah-tengah penderitaan rakyat yang terdampak covid 19 ? 


\section{Literasi Media Komunikasi}

Literasi media ini amat penting dalam kehidupan masyara-kat sebagai pusat per-kembangan literasi media. Dapat diamati bahwa literasi media merupakan serangkai-an cara pandang seseorang dalam meman-faatkan secara efektif dan efisien, ketika media komunikasi diperguna-kan oleh individu aktif, untuk menginterpretasikan makna dari pesan-pesan yang ada di dalam media komunikasi. Literasi media menun-jukkan metode dan tingkatan seseorang dalam menggunakan media komunikasi itu di dalam kehidupannya sehari-hari. Dengan demikian, media komunikasi sering-kali memberikan bentuk konten media komunikasi dengan berbagai macam pengetahuan yang telah terstruktur dalam pemaknaan komu-nikasi sebagai suatu cara memben-tuk konten budaya dalam komuni-kasi lintas budaya (makna; perencanaan komunikasi). Tidak semua yang ada di media komunikasi dapat dijadikan pedoman umum yang baik, pasalnya banyak perilaku pengguna dalam mengatur dan memproses berbagai macam bentuk konten media komunikasi sebagai kegunaan konten media itu yang tidak layak diakses, sehingga memberi-kan dampak media komuni-kasi yang kurang memadai atau cukup buruk bagi perilaku pengguna media komunikasi itu.

Kesempatan ini akses media komunikasi ini, seringkali dinipulasi berbagai bentuk perilaku konten media dalam literasi medianya. Tafsiran media sebagai literasi media ini mendapat perhatian lebih ketika literasi media digunakan atau muncul dihadapan publik. Fakta tersebut mem-perlihatkan efektifitas media komunikasi sangat rentan ditinggalkan oleh seseorang individu dengan individu lainnya, dengan pola komunikasi dalam perencanaan, penyajian atau prosedur, evaluasi penyajian konten tertentu. Karena kesulitan atau ketidak pahaman seseorang dalam perencanaan komuniasi yang dilakukannya.

Literasi media ini memiliki arti penting dalam kehidupan ma-nusia sebagai syarat mutlak dari rangkaian literasi media tersebut. Sebagai analisa data untuk memperoleh data itu sebagai tingkatan literasi media dalam mengakses perencanaan komunikasi. Literasi media dapat dipahami sebagai serangkaian kemampuan me-mahami, menggunakan,mempelajari, dan strategis komunikasi mengenai perilaku pengguna media dalam memanfaatkan dan memberi akses positif mengkomuni-kasikan pesan-pesan (symbol -symbol) yang diberikan oleh media massa dengan "literasi" melek media-nya (media edukasi maupun edukasi media) (Druick 2016).

\section{Manajemen Media Komunikasi Kesehatan}

Komunikasi kesehatan umum-nya dilakukan dalam bentuk: (1) pemasaran sosial yang bertujuan untuk memperkenalkan atau mengu-bah perilaku positif, (2) penyebar-luasan informasi melalui media, dan (3) advokasi, pendampingan komunitas, ke-lompok, atau media masa dengan tujuan memperkenal-kan kebi-jakan, peraturan, dan program-program untuk memper-baharui kese-hatan (Liliweri, 2013). Dalam penelitian ini, komunikasi ke-sehatan dilakukan oleh Millenium Challenge Account Indonesia dalam bentuk kampanye ke daerahdaerah terpilih (Suryana, Sugiana, \& Trulline, 2019). Informasi kesehatan yang di-sampaikan dalam kampanye ini berupa isu stunting, penyebab, dampak dan cara-cara pen-cegahannya.

Kegiatan ini juga fokus pada keluarga sehat yang men-dorong laki-laki dan perempuan aktif erbagi keputusan rumah tangga, sebagai rangkaian tindakan komunikasi yang terencana dengan tujuan menciptakan efek tertentu pada khalayak dalam jumlah yang besar, dilakukan secara ber-kelanjutan dalam kurun waktu tertentu (Rogers \& Storey, n.d.).

Menurut Maman Ukas (2004), bahwa fungsi komunikasi adalah; fungsi informasi, fungsi komando akan perintah, fungsi mempengaruhi dan penya-luran serta fungsi integrasi.

Koehler (2008) menge-mukakan empat fungsi komu-nikasi organisasi, yaitu : 


\section{Fungsi Informasi}

Dari fungsi komunikasi tersebut, bahwa fungsi informasi, dengan melalui komunikasi maka apa yang ingin disampaikan oleh nara sumber atau pemimpin ke-pada bawahannya dapat diberikan dalam bentuk lisan ataupun tertulis. Melalui lisan manajer atau pemimpin dengan bawahan dapat berdialog langsung dalam menyam-paikan gagasan dan ide. Seorang administrator organisasi harus mem-buat keputusan me-ngenai program yang mesti disusun dalam tahapan tertentu berdasarkan informasi dari se-jumlah komponen organisasi yang semuanya bermuara pada ke-butuhan informasi yang tepat waktu, benar dan memiliki validitas tinggi.

\section{Fungsi Regulatif}

Fungsi ini dimaksudkan sebagai proses yang dilakukan manajr yaitu mengawasi perpin-dahan perintah informasi pengi-riman pesan kepada bawahan. Perintah itu dipahami oleh bawahan sebagai peraturan yang harus dikerjakan. Fungsi regulasi akan perintah tentunya berkaitan dengan kekua-saan, di mana kekuasaan orang adalah hak untuk memberi perintah kepada bawahan di mana para bawahan tunduk dan taat dan disiplin dalam menjalankan tugasnya dengan penuh tanggung jawab. Suatu perintah akan berisikan aba-aba untuk pelaksanaan kerja yang harus dipahami dan dimengerti serta yang dijalankan oleh bawahan. Dengan perintah terjadi hu-bungan atasan dan bawahan sebagai yang diberikan tugas.

\section{Fungsi Persuasif}

Dalam fungsi persuasif ber-arti memasukkan unsur-unsur yang meyakinkan dari atasan baik bersifat motivasi maupun bim-bingan, sehingga bawahan merasa berkewajiban harus menalankan pekerjaan atau tugas yang harus dilak-sanakannya. Dalam kegiatan mempengaruhi, komunikator ha-rus luwes untuk melihat situasi dan kondisi di mana bawahan akan diberikan tugas dan tanggung jawab, sehingga tidak merasa bahwa sebenarnya apa yang dilakukan bawahannya itu merupakan beban, ia akan merasakan tugas dan tanggung jawab.

\section{Fungsi Integratif}

Pada fungsi integrasi bahwa organisasi sebagai suatu sistem harus berintegrasi dalam satu total kesatuan yang saling berkaitan dan semua urusan satu sama lain tak dapat dipisahkan, oleh karena itu orang-orang yang berada dalam suatu organisasi atau kelompok merupakan suatu kesatuan sistem, di mana seseorang itu akan saling berhubungan dan saling mem-berikan pengaruh kepada satu sama lain dalam rangka ter-ciptanya suatu proses komuni-kasi untuk mencapai tujuan bersama yang telah ditetap-kan. (Koehler, 1981). Untuk itu dalam rangka meningkatkan efekti-vitas komunikasi dalam orga-nisasi perlu ditingkatkan ke-sadaran akan kebutuhan ko-munikasi yang efektif untuk memperlancar tugas dan pencapaian tujuan.

\section{Komunikasi Sebagai Sistem Komprehensif}

Penyampaian informasi kese-hatan ini, petugas kesehatan perlu memperhatikan kelima un-sur penting dalam komunikasi, yaitu komunikator, pesan yang disampaikan, media untuk penyampaian pesan kesehatan, audience dari pesan tersebut, dan efek yang diharapkan dari proses penyam-paian suatu pesan. Komunikator atau pihak yang mengirimkan atau menyampaikan pesan harus mampu menyam-paikan pesan dengan jelas. Pihak penyampai pesan ini haru sepaham terlebih dahulu apa pentingnya pesan tersebut di-sampaikan serta efek yang diharapkan dari pengiriman pesan tersebut.

Sedangkan lebih lanjut, komunikasi memiliki peranan sebagai berikut:

1. Sebagai media pengirim pesan, dengan tujuan agar orang lain memahami isi ide yang dikirimkan 
2. Pengiriman pesan juga memiliki fungsi spesifik untuk meningkatkan pengetahuan orang lain terhadap sesuatu hal. Konteks ini banyak kita dapatkan dalam konteks komunikasi Kesehatan.

3. Komunikasi juga bertujuan untuk menyampaikan pesan yang berisi komando atau perintah untuk melakukan sesuatu hal, dan,

4. Lebih jauh lagi, komunikasi ini diharapkan akan mem-berikan pengaruh pada orang yang menerima pesan tersebut.

Informasi menjadi hal yang penting dalam kehidupan manusia, salah satunya adalah informasi kesehatan karena ber-hubungan dengan kondisi fisik setiap individu. mengungkapkan pentingnya membagun ketahanan infor-masi nasional dalam perspektif komunikasi kesehatan bagi perempuan urban di era digital. Ketahanan informasi yang dimaksud dalam hal ini tentunya informasi kesehatan.

Ketika teknologi hadir memberikan kemudahan dalam proses komunikasi bermedia, maka informasi kesehatan pun dengan mudahnya dapat diakses oleh kalangan perempuan urban diera tersebut. Dengan meman-faatkan peran media digital, tetapi dalam rangka membangun ketahanan informasi nasional, maka mereka pun memiliki tahapan yang dilakukan dalam pencarian informasi kesehatan secara bermedia. Tahapan tersebut terdiri dari pemilihan sumber yang kredibel; adanya filterisasi kognitif agar tidak terkena informasi kesehatan yang bersifat hoax; memilih media komunikasi yang tepat; serta aktif mencari komunitas yang peduli kesehatan (Prasanti \& Fitriani, 2018).

\section{Minimalisir keraguan Masyarakat soal vaksin covid 19}

Literasi digital dalam bentuk webinar ini mengangkat tema "Komunikasi Inter-personal Pentingnya Vaksin dan Perubahan Perilaku" yang bertujuan untuk meminimalisasi vaccine hesitan-cy atau keengganan dan keraguan masyarakat terhadap vaksin.

Vaccine Hesitancy menjadi salah satu penyebab penghambat terbesar dalam upaya melindungi masyarakat dari penyakit ber-bahaya yang bisa dicegah dengan imunisasi, seperti Covid-19.

Miss-informasi yang ber-edar terkait vaksinasi Covid-19, digadang-gadang menjadi salah satu penyebab semakin tinggi-nya vaccine hesitancy di dalam masyarakat saat ini.

Berdasarkan survei persepsi masyarakat terhadap vaksinasi Covid-19 yang dilakukan Kementerian Kesehatan dan Indonesia Advisory Group on Immunization (ITAGI) dengan dukungan WHO dan UNICEF pada September 2020, menunjukan 65 persen masyarakat menerima vaksin Covid-19.

Namun, pada December 2020 angka penerimaan masyarakat terhadap vaksin Covid-19 turun menjadi 30\%. Risang Rimbatmaja, C4D UNICEF salah satu pembicara dalam webinar mengatakan saat ini terjadi dinamika penerimaan vaksin Covid-19 di dalam masyarakat Indonesia.

"Hal ini disebabkan adanya kesalahan informasi yang diterima masyarakat terkait keamanan efektivitas vaksin, kejadian ikutan pasca Imunisasi (KIPI), sampai dengan teori konspirasi yang saat ini banyak beredar," ujarnya dalam keterangan tertulis yang diterima.

Menurut Risang, pemberitaan media yang berimbang dan akurat mengenai vaksinasi menjadi kunci meningkatkan kepercayaan masyara-kat terhadap vaksinasi. "Literasi digital dan komunikasi interpersonal yang efektif, terutama pada key opinion-leader dalam masyarakat pun juga dapat membantu meningkatkan kepercaya-an masyarakat tersebut," imbuhnya Siberkreasi berharap melalui kegiatan webinar yang dilakukan dengan menghadirkan pakarpakar di bidang-nya, masyarakat memiliki pemahaman yang terbuka dan mendalam tentang vaksinasi Covid-19. 


\section{Peran Media dalam upaya Edukasi masyarakat soal vaksin covid 19}

Pemerintah Indonesia kini tengah mempersiapkan dan melakukan peng-kajian vaksin yang diharapkan akan segera diluncurkan pada 2021 men-datang. Hal tersebut pun mengundang berbagai macam reaksi di masyarakat mengenai informasi vaksin tersebut. Tidak jarang ditemukan berbagai hoaks ataupun informasi tidak jelas tersebar di media social, sehingga peran media diharapkan menjadi pihak penting untuk mengedukasi masyarakat perihal vaksinasi. Lantas, bagaimana peran penting media dalam menyampaikan informasi kepada masyarakat?

Informasi tidak jelas banyak bermunculan di masyarakat, sehingga hal tersebut bisa menjadi salah satu alasan masyarakat menjadi ragu jika vaksin mampu menangkal virus, apalagi memang banyak masyarakat awam tidak tahu dunia kesehatan. Ada juga yang tidak percaya bahwa Covid-19 itu ada, sehingga merasa bahwa vaksin itu tidak perlu,

media merupakan pihak yang harus menjadi sumber valid dalam mengedukasi masyarakat perihal vak-sinasi tersebut. Tidak dapat dipungkiri, tingkat literasi masyarakat Indonesia kini masih terbilang rendah, sehingga diperlukan pihak penting seperti pemerintah dan media dalam upaya sosialisasi mengenai pentingnya vaksinasi di Indonesia. "Jika ingin mengontrol perilaku masyarakat dan meraih keper-cayaan masyarakat, yang pertama kali perlu disentuh jelas media yang ada, khususnya media digital. Perlunya pihak penting berperan untuk memberikan informasi yang jelas dan benar. Kita tidak bisa mengandalkan kesadaran masyarakat dalam menyaring informasi, karena tingkat literasi masyarakat Indonesia yang rendah,

Pemerintah harus merangkul media dalam membantu upaya sosialiasi mengenai vaksin tersebut. Saya rasa masyarakat masih minim informasi akan hal ini, juga ditambah dengan informasi yang beredar sehingga seakan menakuti masyarakat untuk tidak usah melakukan vaksinasi. Pemberitaan informasi yang jelas, detail dan valid merupakan kunci penting dalam meningkatkan kesadaran masya-rakat perihal program vaksinasi tersebut

\section{Peran komik sebagai literasi media di tengah pandemic covid 19}

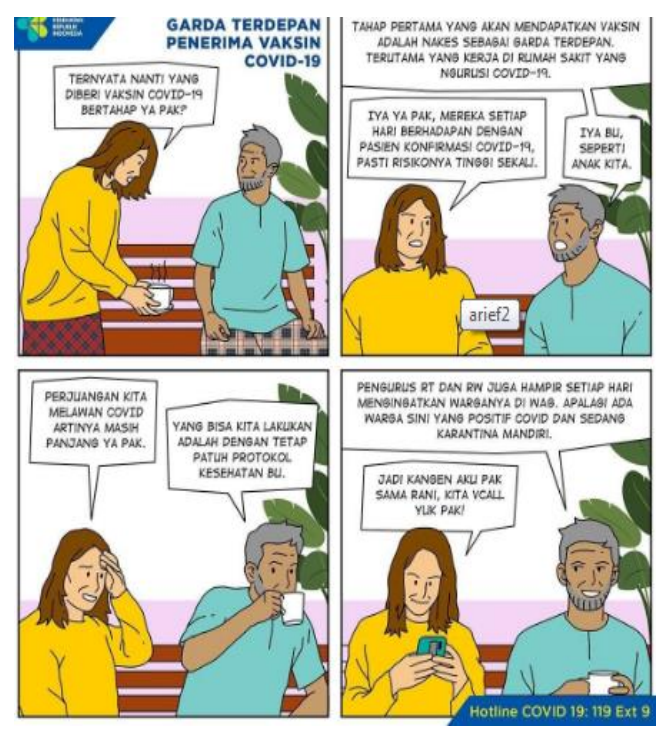

Gambar 3 ilustrasi komik

Ketika awal mula disampaikan kepada publik bahwa ada masyarakat yang terpapar virus COVID 19, seketika itu terjadi kegaduhan dimana-mana. Ke-bimbangan dan kecemasan masyakarat berakibat pada pola pikir dan perilaku yang tidak semestinya. Peristiwa ini terjadi 
di masyarakat salah satunya dalam bentuk perilaku berbelanja yang berlebihan untuk menimbun makanan dan bahan-bahan keperluan lainnya.

Kondisi tersebut kemudian direspon cepat oleh Presiden Joko Widodo (Jokowi) dengan menyampaikan informasi kepada masyarakat. Informasi ini dalam bentuk ilustrasi komik seperti yang terdapat pada gambar 3 dengan isi informasi berupa anjuran untuk tidak panik dalam menyikapi kejadian tersebut. Informasi ini merupakan bagian dari literasi media yang diunggah Presiden Jokowi di akun Instagramnya (@jokowi).

Kemudian, dalam perkembangannya, kegaduhan kembali yang terjadi muncul khususnya terkait vaksin COVID 19. Banyak terjadi penolakan tentang status keberadaan vaksin itu sehingga membuat ketidak percayaan masyarakat. Dengan sigap pemerintah melalui Kementerian Kesehatan memberi-kan informasi dalam bentuk literasi media tentang keamanan dan siapa saja yang wajib mendapatkan vaksin Literasi media dalam bentuk komik itu diunggah di akun resmi Instagram Kementrian Kesehatan (@kemenkes_ri). Komik yang disajikan sangat menarik dan mudah dipahami untuk semua lapisan masyarakat. Literasi masyarakat penting dilakukan karena bahaya mengancam masyarakat dengan literasi rendah. Imbasnya, masyarakat berliterasi rendah lebih mudah dipengaruhi berita tidak benar dan hoaks. Sepanjang pandemi COVID 19, berbagai isu dapat dengan mudah viral di masyarakat. Kecepatan internet menjadi salah satu faktor tersebarnya berbagai isu baik positif maupun negatif. Hal ini membuat kita harus cermat dalam menelaah konten media.

Pada dasarnya, ada enam dampak dari rendahnya budaya literasi masyarakat, yaitu (1) tingginya angka putus sekolah, (2) kebodohan yang tidak berujung, (3) meluasnya kemiskinan, (4) rendahnya nilai produktifitas kerja, dan (5) munculnya kerentanan masyarakat dalam menyikapi informasi menjadi kurang bijaksana (Yunus, 2020). Literasi sejatinya tidak sebatas pada baca dan tulis, tetapi ada pula prinsip-prinsip yang muncul sebagai faktor literasi media (Herlina, 2019).

\section{KESIMPULAN}

Perspektif ekonomi politik berbasis negara pada dasarnya menempatkan negara sebagai sentrum dari berbagai kepen-tingan kelompok (swasta) dan masyarakat menjadi kepentingan nasional. Kresner dalam Caporaso dan Levine (2015)menjelaskan bahwa negara dalam hal ini sebagai institusi yang bertanggung jawab menetapkan nilai-nilai yang digunakan dalam menentukan kegunaan bagi masyarakat. Empirisnya, perlakuan negara dari vaksin covid 19 adalah menempatkan masyarakat sebagai subjek utama dalam proses induksi nilai. Dengan kata lain, secara sederhana, pemerintah sekali lagi, harus melihat kondisi masyarakat lebih terbuka dan melihat pula kemampuan objektif masyarakat saat ini. Jika tidak mungkin, maka pemerintah perlu berkorban dalam kondisi rugi sekalipun (Rosyida, 2020). Jika sudah ada keselarasan nilai seperti itu, maka $100 \%$ kesadaran masyarakat akan tumbuh atas kegunaan vaksin.

\section{DAFTAR PUSTAKA}

Agustino, L. (2020). Analisis Kebijakan Penanganan Wabah Covid-19: Pengalaman Indonesia. Junal Borneo Administrator, 16(2), 253-270.Aubin, D. (2009).

Swine flu dampens economy. Reuters.

https://uk.reuters.com/article/uk-financial/swine-flu-dampens-economyidUKTRE53Q0TP20090427Bbcnews. (2020). Covid-19:

Indonesia targetkan impor vaksin pada Desember, relawan: "uji klinis belum selesai kok sudah pesan vaksin jadi?’Bbc.Com. https://www.bbc.com/indonesia/indonesia-54723381 
Boyer, R., \& Drache, D. (1996). States Against Market; The Limits of Globalization. London: Routledge.Budiardjo, M. (2008).

Dasar-Dasar Ilmu Politik. Jakarta: PT Gramedia Pustaka Utama.Calmes, J., \& Jr, D. G. M. (2009).

Swine Flu Is Widespread in 46 States as Vaccines Lag. Gainesville.Com. https://www.gainesville.com/news/20091025/swine-flu-is-widespread-in-46-states-asvaccines-lagCaporaso, J. A., \& Levine, D. P. (2015).

Teori-Teori Ekonomi Politik(2nd ed.). Yogyakarta: Pustaka Pelajar. Chabibi, M. (2019).

Pertaruhan Politik Negara Atas Mekanisme Pasar ( Studi Analisis Ekonomi Politik Menurut John Rawls ). Indonesian Interdisciplinary Journalof Sharia Ecenomic (IIJSE), 1(2), 1628.Choiruzzad, S. A. B. (2020).

Penelitian Kualitatif \& Desain Riset (Terj)(3rd ed.). Yogyakarta: Pustaka Pelajar.Gerth, H. H., \& Mills, C. W. (1958). From Max Weber: Essays in Sociology. New York: Oxford University Press.Hameiri, S., \& Jones, L. (2016).

Rising powers and state transformation: The case of China. European Journal of International Relations, 22(1), 72-98.

https://doi.org/https://doi.org/10.1177/1354066115578952Ihsanuddin. (2020).

Syairozi, M. I., Pambudy, A. P., \& Yaskun, M. (2021). ANALISIS PENERAPAN GOOD GOVERNANCE DALAM SISTEM INFORMASI KEUANGAN DAERAH. Prosiding Penelitian Pendidikan dan Pengabdian 2021, 1(1), 49-59.

Syairozi, M. I. (2011). Analisis peranan sektor pertanian terhadap produk domestik regional bruto (PDRB) di kabupaten Malang (periode 2000-2008) (Doctoral dissertation, Universitas Negeri Malang).

Jokowi Jelaskan Alasan Pemerintah Beli Vaksin Covid-19 yang Belum Lolos Uji Klinis.

Kompas.Com. https://nasional.kompas.com/read/2020/10/26/15243391/jokowi-jelaskan-alasanpemerintah-beli-vaksin-covid-19-yang-belum-lolos-uji?page=all.Inman, P. (2020).

We forget that flu once plagued the economy as coronavirus does today. The Guardian. https://www.theguardian.com/business/2020/may/03/flu-once-plagued-economycoronavirus-war-great-depressionKemenkesRI. (2020).

Situasi Covid 19. Kemenkes RI. https://www.kemkes.go.id/index.php

MacIver, R. M. (1926). The Modern State. New York: Oxford University Press.Miller, C. (2020). Covid19 Crisis: Political and Economic Aftershock.

Foreign Policy Research Institute. https://www.fpri.org/article/2020/03/covid-19-crisispolitical-and-economic-aftershocks/Purwanto, E. A., \& Emilia, O. (2020) (ed).

New Normal Sebagai Jalan Tengah?: Kesehatan vs. Ekonomi dan Alternatif Kebijakan Dalam Pandemi COVID-19.

In New Normal: Perubahan Sosial Ekonomi dan Politik Akibat COVID-19. Yogyakarta: Gadjah Mada University Press.Rasyid. (2000).

Makna Pemerintahan. Jakarta: PT. Mutiara Sumber Widya.Rosyida, N. Z. (2020).

Pemerintah Dituding Cari Untung Lewat Vaksin Covid-19 Berbayar, Erick Thohir Buka Suara. Portaljember.

Pikiran-Rakyat.Com. https://portaljember.pikiran-rakyat.com/nasional/pr-16717451/pemerintahdituding-cari-untung-lewat-vaksin-covid-19-berbayar-erick-thohir-buka-suara.Sari, H. P. (2020).

Indonesia Disebut Berpotensi Jadi Episentrum Baru Covid-19, Ini Respons Jubir Pemerintah Artikel ini. Kompas.Com.

https://nasional.kompas.com/read/2020/04/11/20351811/indonesia-disebut-berpotensi-jadiepisentrum-baru-covid-19-ini-respons-jubirWalliman, N. (2011). Research Methods; The Basics. London: Routledge.Whiting, K. (2020). 